\title{
МІЖНАРОДНО-ПРАВОВІ СТАНДАРТИ ЗАСТОСУВАННЯ СУДОВОГО ШТРАФУ
}

\author{
КОМАРНИЦЬКИЙ Олег Леонідович - здобувач кафедри загальноправових \\ дисциплін Донецького юридичного інституту МВС України \\ ORCID: https://orcid.org/0000-0003-4038-9906 \\ УДК: 343.271 \\ DOI 10.32782/EP.2021.4
}

\begin{abstract}
У статті зазначається, що основна нормативно-правова мета застосування інших заходів кримінально-правового характеру й відтворений застосуванням таких заходів фундаментальний сочіальний ебект полягають у: а) звільненні від кримінальної відповідальності post-factum за вчинення кримінально-караних діянь; б) сприянні поточній $i$ подальшій сочіально сприятливій, законослухняній поведіниі правопорушника.

Зважаючи на особливості й надзвичайний ступінь тяжкості злочинів з сучасного міжнародного кримінального права та злочинів міжнародного масштабу, важливим видається розглянути проблематику наявності й змісту в сучасному міжнародному кримінальному праві норм, що передбачають застосування інших заходів кримінально-правового характеру.

Робиться висновок про те, що в сучасному міжнародному кримінальному праві як відсутній, так $i$ наявний нормативізований розподіл між «основними» видами кримінальних покарань та низкою «додаткових» «обмежувальних», «каральних», «виховних» заходів.

У першому випадку бактична наявність у сучасному міжнародному кримінальному праві заходів, прямо або побічно відповідних нормативно-правовому змістові інших заходів кримінально-правового характеру, не відтворюе проте їхнього бормально-юридичного виокремлення від інституту кримінального покарання.

Інститут таких норм, залежно від кон-
\end{abstract}

кретного джерела сучасного міжнародного кримінального права, багато в чому відповідає суті, характерним сутнісним ознаками, критеріями, природі, соціальному, нормативноправовому й функиійно-иільовому призначенням та різновидам аналогічних національних кримінально-правових норм.

Отже, як вітчизняні, так $i$ міжнародні норми щодо інших заходів кримінально-правового характеру мають стати предметом подальших дискусій у межах вітчизняної й світової науково-правничої спільноти.

Ключові слова: міжнародно-правовий, стандарт, судовий штраф, звільнення від покарання, звільнення від кримінальної відповідальності.

Згідно 3 концепцією сучасного кримінального права, правові наслідки вчинення певного кримінально-караного діяння можуть мати не тільки кримінально-правовий а й, скажімо, альтернативно-правовий і соціальний характер.

Тому сучасне національне кримінальне право багатьох держав відтворює нормативно-правові підстави, які передбачають або звільнення правопорушника від кримінальної відповідальності й застосування до нього виключно некримінальних заходів сочіального впливу, або ж сукупне застосування до правопорушника тих чи інших кримінальних покарань і згаданих некримінальних заходів.

Основна нормативно-правова мета застосування інших заходів кримінально-правового характеру й відтворений застосуван- 


\section{Теорія, історія держави і права, конституційне право}

ням таких заходів фундаментальний соціальний ефект полягають у: а) звільненні від кримінальної відповідальності post-factum за вчинення кримінально-караних діянь; б) сприянні поточній) і подальшій соціально-сприятливій, законослухняній поведінці правопорушника.

Зважаючи на особливості й надзвичайний ступінь тяжкості злочинів 3 сучасного міжнародного кримінального права та злочинів міжнародного масштабу, важливим видається розглянути проблематику наявності й змісту в сучасному міжнародному кримінальному праві норм, що передбачають застосування інших заходів кримінально-правового характеру.

Різноманітні тяжкі й зазвичай непереборні соціально-гуманітарні наслідки вчинення злочинів з сучасного міжнародного кримінального права й злочинів міжнародного масштабу впливають на досить численні соціальні спільноти, великі соціальні структури, втілені в цілих народах, інституалізовані в їхніх культурі, економіці, державах.

Тому особа, яка свідомо вчинила той чи інший злочин із сучасного міжнародного кримінального права або ж злочин міжнародного масштабу, несе надзвичайну правову, соціальну й моральну відповідальність за свої діяння, що однак не повинно виключати чіткої нормативно-правової бази для застосування до такої особи комплексу інших заходів кримінально-правового характеру.

Саме тому надзвичайно актуальним i важливим є звернення до проблематики наявності, типології й змісту комплексу інших заходів кримінально-правового характеру в сучасному міжнародному кримінальному праві.

Необхідне здійснення новітніх наукових досліджень е межах такої окремої й цілісної проблематики сучасного міжнародного кримінального права надає для вчених-правознавців, юристів-практиків, а також уповноважених законодавців і посадових осіб можливість розробляти й вносити грунтовні проєкти корисних, новаторських законодавчих поправок, спрямованих на прогресивне й зважене реформування відповідних норм сучасного міжнародного та національного кримінального права.

У цій статті, відповідно до чітко сформульованої й актуалізованої тематичної проблеми, презентуємо й розглянемо правове й соціальне функційно-цільове призначення й зміст сукупності предметно-регулятивних норм сучасного міжнародного кримінального права, які передбачають підстави, принципи, порядок та наслідки застосування інших заходів кримінально-правового характеру за вчинення злочинів із сучасного міжнародного кримінального права або ж злочинів міжнародного масштабу.

Передусім слід зазначити, що у вітчизняних науково-правознавчих колах триває конструктивна дискусія, спрямована на виявлення специфічної сутності, чітких критеріїв, характерних виявів і функційно-цільового призначення інституту інших заходів кримінально-правового характеру в цілому.

Під іншими заходами кримінально-правового характеру слід розуміти встановлені кримінальним законом заходи державного примусу, що застосовують на підставі рішення суду до осіб, що вчинили діяння, яке заборонене кримінальним законом i яке полягає в обмеженні їхніх прав і свобод [1, с. 17].

У сучасному кримінальному праві широкого кола держав такі заходи нормативно дефінують не як «інші заходи кримінально-правового характеру», а як «заходи безпеки». Проте в деяких країнах їх називають по-іншому, зокрема в Німеччині та Греції - «заходи виправлення й безпеки» (\$ 61-70 КК ФРН), в Італії, Іспанії, Сомалі - заходи безпеки (ст. 202-228 КК Італії; ст. 95-105 КК Іспанії; ст. 162-180 КК Сомалі) [2, с. 83].

Зазначені спірно-предметні позиції логічно відтворюють й іншу непросту проблематику - проблематику визначення конкретних нормативних видів / прикладів інших заходів кримінально-правового характеру.

Переходячи до розгляду міжнародних кримінально-правових норм, що передбачають застосування заходів, які можна розглядати як інші заходи кримінально-правового характеру, слід викласти такі фундаментальні нормативно-правові положення. 
Як відомо, згідно зі ст. 1 Римського Статуту Міжнародного кримінального суду (далі - Статут Суду), підписаного 17 липня 1998 року і який набрав чинності 1 липня 2002 року, злочини, що підпадають під його правову юрисдикцію, у нормативно-правовому й морально-ціннісному аспекті визначають / характеризують як «найсерйозніші злочини, що викликають схвильованість усієі міжнародної спільноти» [3].

До таких злочинів і їхніх різновидів / проявів згідно з досить докладним змістом ст. 5, 6, 7 і 8 віднесено тільки (!): а) злочин геноциду; б) злочини проти людяності; в) військові злочини; г) злочин агресії [3].

Отже, йдеться саме про викладене вище тлумачення суті, характеру й масштабів соціальних, моральних, культурних та інших наслідків вчинення злочинів із сучасного міжнародного кримінального права та злочинів міжнародного масштабу.

Норма про кримінально-правову юрисдикцію Суду, тобто норма про юрисдикцію, подібну за характером до юрисдикції судових інстанцій суверенних держав, міститься в ч. 1 і ч. 2 ст. 25 «Індивідуальна кримінальна відповідальність» Частини 2 «Юрисдикція, прийнятність і застосовне право» Статуту Суду: «1. Суд має юрисдикцію щодо фізичних осіб відповідно до цього Статуту. 2. Особа, яка вчинила злочин, що підпадає під юрисдикцію Суду, несе індивідуальну (кримінальну. - авт.) відповідальність і підлягає покаранню відповідно до цього Статуту» [3].

У п. с) ч. 1 зазначеної ст. 21 Статуту Суду наголошено: "Якщо це неможливо (тобто якщо неможливо застосування згідно 3 п. а) і п. в) цієї ж ч. 1 зазначеної ст. 21, 3 положеннями самого Статуту, міжнародними договорами, принципами й нормами міжнародного права, а також загальновизнаними принципами міжнародного права збройних конфліктів. - авт.), Суд застосовує загальні принципи права, взяті ним із національних законів правових систем світу, i, вiдnовідно, нащіональні закони держав (курсив мій. - Авт.), які за звичайних обставин здійснювали 6 юрисдикцію відносно зазначеного злочину за умови, що ці принципи не $є$ несумісними із Статутом і міжнародним правом, а також міжнародно визнаними нормами i стандартами» [3].

Що ж стосується безпосередньо самих видів заходів кримінально-правового характеру (в цьому випадку без слова «інші»), які застосовують за вчинення злочинів, передбачених ст. 5, 6, 7 і 8 Статуту Суду, то такі нормативізовані у ст. 77 «Застосовувані заходи покарання» Частини 7 «Заходи покарання» Статуту Суду.

Так, у ч. 1 і ч. 2 зазначеної статті Статуту Суду йдеться: «1. 3 урахуванням статті 110 Суд може призначити один із таких заходів покарання особі, визнаній винною у скоєнні злочину, передбаченому ст. 5 цього Статуту: а) позбавлення волі на певний строк, який обчислюється в кількості років, що не перевищує максимальної кількості в 30 років, або b) довічне позбавлення волі в тих випадках, коли це виправдано тільки тяжким характером злочину та індивідуальними обставинами особи, визнаної винною в його скоєнні.2. Крім (курсив мій. - Авт.) позбавлення волі, Суд може призначити: а) штраф відповідно до критеріїв, передбачених у Правилах процедури та доведення; b) конфіскацію доходів, майна й активів, отриманих прямо або побічно в результаті злочину, без шкоди для прав bona fide третіх сторін» [3].

Отже, виходячи 3 наведених положень ст. 77 «Застосовні заходи покарання» Частини 7 «Заходи покарання» Статуту Суду, можна зробити певні висновки.

По-перше, сучасне міжнародне кримінальне право, а в такому випадку саме Статут Суду, згідно зі ст. 77 «Застосовні заходи покарання» Частини 7 «Заходи покарання» Статуту Суду, «словесно», «буквально», «теоретично», «понятійно», «дефініційно» i, отже, «формально» / «легально» не оперує тим, що має назву «інші заходи кримінальноправового характеру».

По-друге, тим не менше, обидва заходи кримінально-правового характеру (знову ж таки в такому випадку без слова «інші»), зазначені в п. а) і п. b) ч. 2 ст. 77 «Застосовні заходи покарання» Частини 7 «Заходи покарання» Статуту Суду, є фактичними, хоча, треба визнати, й досить відносним, «недослівним» аналогом «інших заходів кримінально-правового характеру». 


\section{Теорія, історія держави і права, конституційне право}

По-третє, зазначене твердження нехай і побічно, проте все таки підтверджене тим, що обидва «додаткові» заходи кримінальноправового характеру (знову ж таки в такому випадку без слова «інші»), зазначені в п. а) і п. b) ч. 2 ст. 77 «Застосовні заходи покарання» Частини 7 «Заходи покарання» Статуту Суду, застосовуються крім (!) позбавлення волі на певний строк або ж крім довічного позбавлення волі.

По-четверте, обидва «додаткові» заходи кримінально-правового характеру (знову ж таки в такому випадку без слова «інші»), зазначені в п. а) і п. b) ч. 2 ст. 77 «Застосовні заходи покарання» Частини 7 «Заходи покарання» Статуту Суду, виступають лише як доповнення, але не альтернатива двох «основних» заходів кримінально-правового характеру, зазначених у п. а) і п. b) ч. 1 ст. 77 «Застосовні заходи покарання» Частини 7 «Заходи покарання» Статуту Суду.

По-n'яте, на жаль (!), обидва «додаткові» заходи кримінально-правового характеру (знову ж таки в такому випадку без слова «інші»), зазначені в п. а) і п. b) ч. 2 ст. 77«Застосовні заходи покарання» Частини 7 «Заходи покарання» Статуту Суду, перебувають у безпосередньому / «нерозривному» нормативно-правовому та фактичному взаємозв'язку 3 інститутом саме покарання як таким, що проявляється, своєю чергою, у вигляді двох «основних» каральних заходів кримінально-правового характеру, зазначених у п. а) і п. b) ч. 1 ст. 77 «Застосовні заходи покарання» Частини 7 «Заходи покарання» Статуту Суду.

Отже, обидва «додаткові» заходи кримінально-правового характеру (знову ж таки в такому випадку без слова «інші»), зазначені в п. а) і п. b) ч. 2 ст. 77 «Застосовні заходи покарання» Частини 7 «Заходи покарання» Статуту Суду номінально й фактично не відображають змісту поняття й критеріїв «інших заходів кримінально-правового характеру» $\mathrm{i}$ / або «заходів безпеки». У такому контексті слід зазначити, що, як бачимо, в ч. 2 ст. 77 «Застосовні заходи покарання» Частини 7 «Заходи покарання» Статуту Суду не передбачено «класичних» «інших заходів кримінально-правового характеру»: примусових заходів медичного характеру та захо- дів виховного, виправного та коригувального впливу.

По-шосте, інститут застосування обох «додаткових» заходів кримінально-правового характеру (знову ж таки в такому випадку без слова «інші»), зазначених у п. а) і п. b) ч. 2 ст. 77 «Застосовні заходи покарання» Частини 7 «Заходи покарання» Статуту Суду, є невід'ємним від інституту міжнародної кримінальної відповідальності особи. Так, згідно зі ст. 31 «Підстави для звільнення від кримінальної відповідальності» Частини 3 «Загальні принципи кримінального права» Статуту Суду таке звільнення не тягне за собою застосування до правопорушника ані «основних», ані «додаткових» заходів кримінально-правового характеру, зазначених відповідно в п. а ) і п. b) ч. 1 і ч. 2 ст. 77 «Застосовні заходи покарання» Частини 7 «Заходи покарання» Статуту Суду.

Проте не слід забувати й про згадану можливість законної керованості Суду нормативно-правовим положенням вищенаведеного п. с) ст. 21 «Застосовне право» Частини 2 «Юрисдикція, прийнятність і застосовне право» Статуту Суду.

Слід зазначити, що відповідно до п. а) ч. 1 згідно зі ст. 31 «Підстави для звільнення від кримінальної відповідальності» Частини 3 «Загальні принципи кримінального права» Статуту Суду, особа може бути звільнена від кримінальної відповідальності, якщо на момент вчинення нею діяння особа страждає на психічне захворювання або розлад, який позбавляє ії можливості усвідомлювати протиправність або характер своєї поведінки або погоджувати свої дії з вимогами закону [3].

Також зазначимо, що відповідно до ч. 3 ст. 23 «Заходи покарання» Статуту Міжнародного кримінального трибуналу щодо Руанді, а також ч. 3 ст. 24 «Заходи покарання» Статуту Міжнародного кримінального трибуналу щодо колишній Югославії, єдиним «додатковим» заходом кримінальноправового характеру, який застосовується крім тюремного ув'язнення, є повернення правопорушником будь-якого майна та доходів, отриманих у результаті злочинної поведінки, зокрема шляхом примусу, їхнім законним власникам [4-5]. 
Однак, як відомо, Статути та Статути міжнародних кримінальних судів і міжнародних кримінальних трибуналів не є єдиними джерелами сучасного міжнародного кримінального права.

Наприклад, чинна Конвенція ООН 3 боротьби проти незаконного обігу наркотичних засобів і психотропних речовин від 19 грудня 1988 року (далі - Конвенція) є яскравий приклад наявності кримінальноправових норм, що передбачають законну можливість застосування до правопорушника інших заходів кримінально-правового характеру як доповнення до кримінальних покарань або ж альтернатива таким.

Так, згідно 3 п. а) ч. 4 ст. 3 «Правопорушення й санкції» Конвенції як власне кримінальні покарання передбачені тюремне ув'язнення, або інші види позбавлення волі, штрафні санкції та конфіскація [6].

Положення п. b), п. с) п. d) ст. 3 «Правопорушення й санкції» Конвенції відтворюють зміст, визначення, критерії та функційно-цільове призначення інших заходів кримінально-правового характеру та їх різновидів: «b) сторони можуть передбачити на додаток (курсив мій. - Авт.) до засудження або покарання за правопорушення, визнане таким згідно з пунктом 1 цієї статті, застосування щодо правопорушника таких заходів, як лікування, перевиховання, подальше спостереження за ним, відновлення працездатності або соціальна реінтеграція (курсив мій. - Aвm.); с) незважаючи на положення попередніх пунктів, у відповідних випадках, коли відбуваються незначні правопорушення, Сторони можуть передбачити як альтернативу (курсив мій. - Авт.) засудженню або покаранню такі заходи, як перевиховання, відновлення пращездатності або сощіальна реінтеграчія (курсив мій. - Авт.), а також, якщо правопорушник є наркоманом, його лікування й подальше спостереження (курсив мій. Авт.) за ним; d) сторони можуть передбачити або замість засудження або покарання, або на додаток до засудження або покарання (курсив мій. - Aвт.) за правопорушення, визнане таким згідно з пунктом 2 цієї статті, заходи для лікування, виховання, спостереження після закінчення лікування, відновлення працездат- ності й соціальної реінтегращї правопорушника (курсив мій. - Авт.)» [6].

Отже, виходячи з усього вищевикладеного, є підстави зробити певні висновки. У сучасному міжнародному кримінальному праві, за нашими спостереженнями, в цілому відтворений інститут інших норм кримінально-правового характеру як інститут «додаткових», «суміжних», «паралельних», «окремих» кримінально-правових норм, які законно доповнюють або замішують інститут кримінального покарання, незважаючи на повну відсутність відповідної точної або приблизної нормативно-предметної термінології.

Як ми з'ясували, в сучасному міжнародному кримінальному праві як відсутній, так і наявний нормативізований розподіл між «основними» видами кримінальних покарань та низкою «додаткових» «обмежувальних», «каральних», «виховних» заходів.

У першому випадку фактична наявність у сучасному міжнародному кримінальному праві заходів, прямо або побічно відповідних нормативно-правовому змістові інших заходів кримінально-правового характеру, не відтворює проте їхнього формально-юридичного виокремлення від інституту кримінального покарання.

Інститут таких норм, залежно від конкретного джерела сучасного міжнародного кримінального права, багато в чому відповідає суті, характерним сутнісним ознакам, критеріям, природі, соціальному, нормативно-правовому й функційно-цільовому призначенням та різновидам аналогічних національних кримінально-правових норм.

Отже, як вітчизняні, так і міжнародні норми щодо інших заходів кримінальноправового характеру мають стати предметом подальших дискусій у межах вітчизняної й світової науково-правничої спільноти.

\section{入iтepaтypa}

1. Скрипченко Н.Ю. Понятие и виды иных мер уголовно-правового характера. Вестник института: преступление, наказание, исправление. 2011. № 2. С. 16-21.

2. Минязева Т.Ф., Абдикарим Али Ахмед. Иные меры уголовно-правового харак- 


\section{Теорія, історія держави і права, конституційне право}

тера в России и Сомали. Общество и право. 2014. № 3 (49). С. 83-88.

3. Римский Статут Международного уголовного суда от 17 июля 1998 года. URL: http://zakon3.rada.gov.ua/laws/show/995_588/ page.

4. Устав Международного уголовного трибунала для судебного преследования лиц, ответственных за геноцид и другие серьезные нарушения международного гуманитарного права, совершенные на территории Руанды, и граждан Руанды, ответственных за геноцид и другие подобные нарушения, совершенные на территории соседних государств, в период с 1 января 1994 года по 31 декабря 1994 года. URL: http://www. un.org/ru/law/ictr/charter.shtml.

5. Устав Международного трибунала для судебного преследования лиц, ответственных за серьезные нарушения международного гуманитарного права, совершенные на территории бывшей Югославии с 1991 года. URL: http://www.un.org/ru/law/icty/charter. shtml.

6. Конвенция ООН о борьбе против незаконного оборота наркотических средств и психотропных веществ от 19 декабря 1988 года. URL: http://base.garant.ru/10103917/5ac 206a89ea76855804609cd950fcaf7.
The article notes that the main normative-legal goal of applying other measures of a criminal-legal nature and the fundamental social effect reproduced by the use of such measures are: a) release from postfactum criminal liability for committing criminal acts; b) promoting the current and further socially favorable, law-abiding behavior of the offender.

Taking into account the peculiarities and extreme severity of crimes in modern international criminal law and crimes of an international scale, it is important to consider the problem of the presence and content in modern international criminal law of norms that provide for the application of other measures of a criminal legal nature..

It is concluded that in modern international criminal law, there is both no and there is a normative distribution between the «main» types of criminal punishment and a number of «additional», «restrictive», "punitive», «educational» measures.

In the first case, the actual presence in modern international criminal law of measures that directly or indirectly correspond to the normative legal content of other measures of a criminal legal nature, however, does not reproduce their formal legal separation from the institution of criminal punishment.

The institution of such norms, depending on the specific source of modern international criminal law, largely corresponds to the essence, characteristic essential features, criteria, nature, social, regulatory and functional purpose, and varieties of similar national criminal law norms.

So, both domestic and international norms in relation to other measures of a criminal-legal nature should become the subject of further discussion within the framework of the domestic and world scientific and legal community.

Key words: international law, standard, court fine, release from punishment, release from criminal liability. 